ЛАПШИН Аркадий Олегович - кандидат исторических наук, главный редактор журнала «Власть», член президиума Академии политической науки. (117218, Москва, ул. Кржижановского, 24/35, кopnyc 5, oфuc 512; ark2050@yandex.ru)

\title{
ШКОЛА МОЛОДОГО ЭТНОПОЛИТОЛОГА В РЕСПУБЛИКЕ БАШКОРТОСТАН И ЖУРНАЛ «ВЛАСТЬ»: ТВОРЧЕСКИЙ ТАНДЕМ
}

\begin{abstract}
Аннотация. Главный редактор журнала «Власть» пишет о необходимости постоянной и кропотливой работы с молодыми начинающими авторами, специализирующимися в области социогуманитарных наук. Он подчеркивает, что работа такого рода должна вестись всеми высокорейтинговыми журналами, так как поддержка молодых авторов в сегодняшних условиях становится важнейшей государственной задачей.

Ключевые слова: социогуманитарная наука, журналы, молодые кадры, информационная открытость, фейкизация медиапространства, Школа молодого этнополитолога
\end{abstract}

УХурнал «Власть» существует с августа 1993 года. За истекшее время он Х занял прочное место среди социогуманитарных изданий по профилям истории, социологии и политологии. Сотни и сотни статей, экспертных разработок, материалов конференций и круглых столов нашли своего читателя за этот период. Мы стараемся поддерживать высокий профессиональный уровень наших публикаций, допуская в них различные авторские методологические подходы и интерпретации. Это нормально для научного знания. Как известно, без разномыслия не может быть творческого поиска, строгих экспертных заключений, эвристических движений к новому. Ведь новое всегда первоначально выступает как гадкий утенок, падчерица, некая ненормальность.

Но в рамках редакционной политики особое место занимает работа с молодыми, начинающими авторами. Уже не первый год выпускники Финансового и Плехановского университетов проходят у нас практику. По ее итогам и на основе выбранных тем дипломанты имеют возможность опубликовать свои статьи. Не все в научном сообществе согласны с тем, что мы публикуем совсем молодых, начинающих ученых. Но я и мои коллеги по редакции считаем, что эта работа, безусловно, важная, нужная и ее необходимо продолжить. И мы полагаем, что все высокорейтинговые журналы просто обязаны вести работу с начинающими специалистами. Нет другого пути, который бы обеспечивал преемственность и развитие российской науки вообще и социогуманитарного знания в частности.

В последнее время журнал «Власть» стал тесно сотрудничать со Школой молодого этнополитолога в Республике Башкортостан, которая работает при поддержке Фонда президентских грантов. Совместная работа, а это и отдельные публикации, и проведение различных коллективных мероприятий - позволяет начинающим специалистам под руководством опытных коллег быстрее и профессиональнее входить в сферу своей деятельности. В условиях пандемии, когда сократились непосредственные контакты, поддержка молодых кадров становится важнейшей государственной задачей. В условиях информационной открытости (и молодежь ею активно пользуется), при обостряющемся противостоянии в этой сфере и при бурном росте фейкизации современного медиапространства, сохранение у молодежи гражданского и патриотического мировоззрения является залогом устойчивого развития нашего Отечества, 
позволяет сохранить национально-государственной суверенитет и государственную целостность. Ведь ни для кого не секрет, что массовая информация и элементы новой клиповой культуры поступают со стороны сете-коммуникационной сферы, и, как правило, они не совпадают с нашими традиционными ценностями. Как этому противодействовать? Как обеспечить успешное функционирование российской «мягкой силы»? Только совместными усилиями, с вовлечением в неё молодых профессионалов нам удастся сохранить социокультурную идентичность, и соединить тем самым фундаментальные ценности нашей духовности с новейшими процессами развития. Ориентация на технонауку, узкопрагматический подход к образованию действительно позволит достаточно быстро убить фундаментальную науку в России. Совершенно не приемлема модель государственной молодежной политики, реализующейся через концепцию экономики услуг. Не все и вся можно и нужно коммерционализировать. Разве мы хотим, чтобы наши студенты оказались в плену клипового сознания и примитивного информационного контента? Кто и как этому может помешать?

В этом процессе ключевую роль играет соответствующая государственная политика. Мнение, что государство не должно заниматься сферой мировоззрения, медийной и идеологической сферами не выдерживает критики. Это напоминает известный тезис о том, что «рынок все решит». Но мы помним, какой рынок утвердился у нас в 90-е годы, как и в чью пользу проходил демонтаж советской системы собственности. Государства не может быть много или мало, его должно быть достаточно для обеспечения устойчивого инновационного развития страны, для сохранения ее национального и информационного суверенитета.

Школа молодого этнополитолога позволяет через свои площадки (очные и заочные) соединять молодое поколение ученых с опытными профессионалами. Кто, чему и как будет учить подрастающих гуманитариев, зависит от успешной организации и таких структур как Школа молодого этнополитолога в Республике Башкортостан. Вокруг нее собирается актив крупнейших российских специалистов: историков, философов и политологов. По итогам различных круглых столов и мозговых атак на площадке журнала «Власть» уже появляются разнообразные публикации. Вне всякого сомнения, необходимо продолжить эту работу.

Привлечение молодых ученых к серьезной экспертно-аналитической работе позволяет не только повысить их профессиональный уровень, но и сохранить молодых специалистов для Отечества. Не секрет, что некоторая их часть, по данным социологов, стремится уехать из России.

Заинтересовать молодых специалистов творческой работой, обеспечить в дальнейшем для них возможность публикаций тоже является одной из важнейших задач Школы. В тандеме с журналом «Власть» эта деятельность будет продолжена. Государство может и просто обязано поддержать эту важную работу.

Все научные статьи раздела полностью подготовлены к публикации (редактура и корректура) Школой молодого этнополитолога в Республике Башкортостан 


\title{
SCHOOL OF YOUNG ETHNOPOLITICAL SCIENTIST IN THE REPUBLIC OF BASHKORTOSTAN AND THE VLAST' MAGAZINE: CREATIVE TANDEM
}

\begin{abstract}
The editor-in-chief of the Vlast' magazine writes about the need for constant work with young budding scientists which specialize in the field of social sciences and humanities. He emphasizes that work of this kind should be carried out by all high-ranking journals, since the support of young authors in today's conditions is becoming the most important state task. Keywords: socio-humanitarian science, magazines, young budding scientists, information openness, fake media space, School of Young Ethnopolitical Scientist
\end{abstract}

ВАХИТОВ Рустем Ринатович - кандидат философских наук, доцент ФГБОУ ВО БашГУ (450076, Республика Башкортостан, г. Уфа, ул. Заки Валиди, д.32; rust_r_vahitov@таil.ru)

\section{НАЦИОНАЛИЗМ И ИНТЕРНАЦИОНАЛИЗМ: ДВА ЛИКА МОДЕРНА}

Аннотация. Статья посвящена историческому развитию таких понятий, как национализм и интернационализм, приводятся их оригинальные определения. Автором на основании исследований доказывается постулат о том, что эти понятия не являются абсолютными противоположностями, но естественно порождаются самой действительностью.

Ключевые слова: национализм, интернационализм, общество, государство, народ, либерализм, коммунизм

$\mathrm{H}$ ационализм и интернационализм принято воспринимать как полные абсолютные противоположности. Национализм соотносят с правым сегментом политически-идеологического спектра, интернационализм - с левым. Исходя из этого, национализм сближают с консерватизмом и даже с традиционализмом. Мы намерены ниже показать, что это глубокое заблуждение, и что национализм и интернационализм, кстати говоря, и возникшие не так давно, вместе с миром модерна, которому от роду не более трехсот лет, плоть от плоти порождения этого мира.

Для начала дадим определение и национализму, и интернационализму, чтоб было понятно, о чем идет речь (тем более что оба этих термина настолько затасканы в публицистике, что понимаются зачастую просто как оценки, а не как политологические и социально-философские категории, обладающие логическим, очерченным той или иной наукой содержанием). Естественно, мы не настаиваем, что наши определения будут истинами в последней инстанции, наша цель - лишь открыто зафиксировать: из чего мы исходим в наших рассуждениях. Итак, национализм, по нашему мнению - это идеология, которая высшей ценностью считает интересы данной конкретной нации, ее самовоспроизведение, увеличение ее могущества и т.д. В условиях господства идео- 